\title{
Overview of Active and Passive Systems for Treating Acid Mine Drainage
}

\author{
Vikram Seervi $^{1}$, H.L. Yadav ${ }^{2}$, S.K. Srivastav ${ }^{3}$, A. Jamal ${ }^{4}$ \\ M Tech, Student, Department of Mining Engineering, Indian Institute of Technology, (BHU) Varanasi, India ${ }^{1,3}$ \\ Research Scholar, Department of Mining Engineering, Indian Institute of Technology, (BHU) Varanasi, India ${ }^{2}$ \\ Professor, Department of Mining Engineering, Indian Institute of Technology, (BHU) Varanasi, India ${ }^{4}$
}

\begin{abstract}
Acid mine drainage is among one of the qualitative pollution created mainly by mining activities. Water drained from active or abandoned mine workings is often indicated by low $\mathrm{pH}(\mathrm{pH}$ value less than 5.6) with high concentrations of heavy iron and metals sulfate. This water is commonly referred as AMD. Acid mine drainage (AMD) is known to be one of the most severe environmental problem throughout the world in the mining affecting the environment as well as the economics of metal and coal mining operations. Acid mine drainage is also called as "acid rock drainage." This review describes the sources of AMD, pollutions created by AMD and also summarizes the method and application of active and passive techniques for treatment of AMD.
\end{abstract}

Keywords: Sources of AMD active and passive treatment technology, environmental, chemical and biological treatment, wetlands.

\section{INTRODUCTION}

The purpose of mining operations is to full fill the demand for metals and coal resources to support the industrial development for improving the quality of life of the population, as these metals and coal resources are used as raw materials in agriculture, food, construction, energy, transport, and technology in our daily lives, and are vital for technological, economic and social development [1]. However, the mining operations create several environmental problems, and one of them is Acid mine drainage (AMD). AMD generated from the mining of metal or coal contains high acidity [2,3](i.e., low $\mathrm{pH}$ formed by sulfide oxidation) and many heavy and toxic metals which have known to be adverse effects on aquatic life and human beings[4].This paper describes a concise review of sources AMD in mines, afterward a brief of treatment methods. Terminology and technical descriptions in this article have been kept simple so as to provide a review that can be used by the reader. For more technical details, please refer to the specific research articles.

\section{SOURCES OF AMD}

The main sources of AMD are sulfide minerals which one present in sulfide form in coal and metal ores are categorized as primary and secondary sources are as follows:

Primary sources are Mine rock dumps, tailings ponds, Underground and open pit mine workings, underground pumped water, diffuse seeps from replaced overburden in rehabilitated areas, construction rock used in railway, haulage roadways, dams, etc.

Secondary sources are Mineral processing sludge pounds, rock chips, concentrated load-out, stockpiles, concentrate spills along roads, emergency ponds [5].

\section{III.TREATMENT TECHNOLOGIES FOR AMD}

Numerous of the method have been used worldwide for dealing with AMD. These technologies use one or a combination of chemical, physical and biological processes. Treatment of AMD is broadly categorized in active and passive treatment.

Active treatment -Mechanical addition of alkaline chemicals to the effluent is used $\mathrm{pH}$ and precipitate metals.

Passive treatment - Naturally occurring chemical and biological reactions occur in a controlled microbiological chemical reactor without powered mechanical assistance (most of the time).

The active treatment system requires more unit processes, and it is more complicated, and higher process costs compared to the easiest and uncomplicated passive treatment system. Its overall operating cost is very low as compare to another treatment process[3]. 


\section{IARJSET

\section{A. Active treatment technologies for AMD treatment:}

The Active AMD treatment technologies are treatment of AMD utilizing alkaline substance to increase its $\mathrm{pH}$, counteract acidity and to precipitate heavy and toxic metals. Although active treatment technologies are costly when the cost of equipment and machines, chemicals and manpower employed are taken into account[6].

\section{Chemical precipitation:}

Removal of metals can be facilitated by neutralization using a hydroxide precipitate-caustic soda treatment. Addition of an alkaline material to AMD will raise its $\mathrm{pH}$, accelerate the rate of chemical oxidation of ferrous iron (for which active aeration, or addition of a chemical oxidizing agent such as hydrogen peroxide, is also necessary), and causes many of the metals present in the solution to precipitate as hydroxides and carbonates .Often, chemical neutralization is accomplished with slaked lime or calcium carbonate added directly to the water.

Standard alkaline chemicals used for active treatment of AMD are:slaked lime $\left(\mathrm{Ca}(\mathrm{OH})_{2}\right)$,burnt lime $(\mathrm{CaO})$, Caustic soda $(\mathrm{NaOH})$, Soda ash $\left(\mathrm{Na}_{2} \mathrm{CO}_{3}\right)$, Ammonia $\left(\mathrm{NH}_{3}\right)$, Magnesium oxide / hydroxide $\left(\mathrm{MgO} / \mathrm{Mg}(\mathrm{OH})_{2}\right)$, Mineral carbonates (eg. Limestone and dolomite etc)[7].

\section{In-Line Aeration:}

There also is In-Line Aeration and Neutralization System (ILS) which incorporates the chemical treatment processes into a functionally closed system where the treatment reactions can be more closely monitored and accelerated to reduce the chemical reagent costs and reaction processing times.

\section{Electro-precipitation:}

Electro-precipitation processes accomplish similar results by the precipitation of metal hydroxides or by metal ion adsorption.

\section{Oxidation:}

It is used for reduction of metals $\left(\mathrm{Fe}^{2+} \mathrm{Mn}^{2+}\right)$ to oxidization of metals $\left(\mathrm{Fe}^{3+}, \mathrm{Mn}^{4+}\right)$.

Mechanism -Transfer oxygen into water.

\section{Reaction -}

$\mathrm{Fe}^{2+}+1 / 4 \mathrm{O}_{2}(\mathrm{aq})+\mathrm{H}^{+}=\mathrm{Fe}^{3+}+1 / 2 \mathrm{H}_{2} \mathrm{O}$

$\mathrm{Fe}^{3+}+3 \mathrm{H}_{2} \mathrm{O}=\mathrm{Fe}(\mathrm{OH})_{3}(\mathrm{~s})+3 \mathrm{H}^{+}$

$\mathrm{Fe}^{2+}+1 / 4 \mathrm{O}_{2}(\mathrm{aq})+5 / 2 \mathrm{H}_{2} \mathrm{O}=\mathrm{Fe}(\mathrm{OH})_{3}(\mathrm{~s})+2 \mathrm{H}^{+}$

Kinetics -slow at low $\mathrm{pH}$, fast at neutral $\mathrm{pH}$.

Other oxidation techniques are cascade aeration, trickle filter aeration, In-line venturi aeration[8].

\section{Dosing with Alkali:}

It is used to raise $\mathrm{pH}$ of acidic waters \& Counteract acidification by metal hydrolysis, e.g.,

$\mathrm{Fe}^{3+}+3 \mathrm{OH}^{-}=\mathrm{Fe}(\mathrm{OH})_{3}(\mathrm{~s})$

Mechanism -addition of alkalinity lime, hydroxide

Reaction $-2 \mathrm{H}^{+}+\mathrm{Ca}(\mathrm{OH})_{2}(\mathrm{~s})=\mathrm{Ca}^{2+}+2 \mathrm{OH}^{-}$

Kinetics -fast [8].

\section{Sedimentation:}

This process removes metal hydroxide solids from suspension. The removal mechanism is gravity based and with the passage of time settling of particles in a pond or clarifier occur. Here adequate retention time is given to settle the particles. In sedimentation large particles settle at a faster rate than small particles. Settling occurs faster in hot water and retention time of $4-5$ hours.

\section{Reverse Osmosis:}

In this process for the treatment of AMD cellophane like semi-permeable cellulose acetate membrane is used to remove contaminants from polluted water. RO is when pressure is applied to AMD water(concentrated side) and forced through the membrane into a more dilute side. This semi - permeable membrane only allows the passage of solvent (water) and not solutions, e.g., $\mathrm{Na}^{+}, \mathrm{Ca}^{2+} \mathrm{Cl}^{-}$) or larger molecules (e.g., glucose, urea, bacteria) [3,9].Reverse osmosis (RO) membranes have been shown to significantly reduce total dissolved solids, heavy metals, organic pollutants, viruses, bacteria, and other dissolved contaminants. This system is more efficient for heavy metal removal at a wide $\mathrm{pH}$ range of 3-11, from inorganic solution with a metals concentration rejection percentage of over $97 \%$ with a metal concentration raRge from 21 to $200 \mathrm{mg} / \mathrm{L}$. These systems also use full for elimination of metals from different industries likes, electroplating, metal finishing, paper and pulp industries, municipal wastewater, coal and metal mining, petrochemical, textile, food processing industries, radioactive wastewater and contaminated groundwater with recovery of aluminium, acid copper, copper cyanide, chromium, gold, nickel and zinc. 


\section{IARJSET

\section{Ion exchange:}

Ion exchange is used for multipurpose in the metal refinery plant, including handling of raw water, recovery of plating chemicals from clean water, purification of plating solutions, wastewater treatment, and wastewater polishing, separation of gas mixtures, and catalysis of organic from cooling water of nuclear reactors[10].

\section{Electrochemical Treatment Technologies:}

As the behavior of metals in solution is a lot proscribed by their electrochemistry, the use of electrochemical Treatment Technologies in the treatment of AMD has accepted some considerations. This process involves the use of electricity to drive reverse chemical reactions. But disadvantage with this technology is the requirement of regular electrical supply and nearby technical support[2,3].

\section{B. Passive treatment of AMD:}

As early as 1978, lots of variations of AMD passive treatment systems were studied by various organizations on the laboratory bench-testing level. The thought behind the passive treatment is to let the naturally occurring chemical and biological reactions that assist in AMD treatment to take place in the controlled environment of the treatment system, and not in the receiving water body. Passive treatment theoretically offers many advantages in comparison to conventional active treatment systems. Adding chemicals and energy-consuming treatment processes are nearly eliminated with passive treatment systems. Also, the operational and maintenance costs of passive systems like minimum inputs, low-skilled work such as technical manpower, chemicals, no external power required, reduce operational and maintenance cost $[11,12]$ are significantly less than active treatment systems. The design of a passive treatment system for AMD requires the knowledge of mine water chemistry, available treatment techniques, and experience. An analytical sampling of the AMD is very significant in the selection of suitable treatment technologies[13].

Passive treatment systems are considered to be ecofriendly, require low energy and environmentally sustainable acidic mine water treatment systems. Selection of appropriate passive treatment system depends on many key factors like the local topography of the area, site characteristics, water chemistry, flow rate of discharged water[14]. Many factors influence the design, effectiveness and optimal life of passive treatment system, like flow rate and volume, the characteristic of the AMD, land availability [15] and characteristic of the site and heavy metal removal.

There are two primary objectives of AMD treatment: raise $\mathrm{pH}$ and remove acidity and eliminate metal sulfides, metal hydroxides and metal carbonates[16].

\section{Aerobic Wetlands:}

An aerobic wetland has a large surface area shallow pond(lined or unlined) filled with organic matter, for example, compost and contain a layer of limestone gravel on the bottom [17] with the nearly horizontal flow of AMD through it. The pond may be planted with wetland species like cattails(Typha, Sphagnum), etc. These plants prevent channeling(e.g., regulate water flow) and also filter and stabilize the accumulating ferric precipitates[18].Aerobic wetlands are the effective treatment option when the incoming water is net alkaline. It is designed for natural oxidation and precipitation of metals like iron, manganese, and other metals from the water[19]. At a place in Ohio, United state, metal sludge is accumulating at a rate of about $30-40 \mathrm{~mm}$ per year [20]. Wetland plants remove heavy and toxic metals from acidic water by adsorption [21]. The metal adsorption capacity of wetlands depends on many factors like concentrations of dissolved metals, dissolved oxygen (DO), air, $\mathrm{pH}$, the alkalinity of AMD, active microbial biomass and the retention time of AMD in the wetland [22].The area of the wetland depends on the influent load entering the wetland. Aerobic wetlands are a good option for long-term treatment in low maintenance and operational costs [12], but these wetlands require longer detention time and huge surface area [22] for acid mine water treatment.

The major factors that should be taken into account for design of a suitable wetland system vary upon site characteristics, are following: biochemical processes, seasons variation, authoritative issues, substrate, sediment control, the influent acidity loads and retention time, morphometry, redox state \& $\mathrm{pH}$, slope of wetland, vegetation density, rate of flow of water and the land available for a wetland [23]. A typical aerobic wetland is shown in Figure 1.



Fig.1.Typical Section of an Aerobic Wetland 


\section{Anaerobic wetlands:}

Anaerobic wetlands are modifications of natural wetlands. Anaerobic wetlands have the depth more than $30 \mathrm{~cm}$ and consist of a lower layer of an organic substrate. Typically in an anaerobic wetland mine water flows horizontally through a layer of thick, oxygen-free fertilizer that is made from a spent mushroom that contains nearly 10 percent calcium carbonate, which breakdown the sulfates and remove the oxygen. Other compost materials may be sawdust, peat moss, and wood chips or hay. The function of the compost is to consume oxygen. They reliance on the lack of oxygen and the promotion of chemical and microbial processes to generate alkalinity.

These wetlands treat incoming net acidic metal-rich water such as AMD from abandoned metal mines[19]. According to [24], anaerobic wetlands are used to treat net acidic discharge be sized by a factor of $3.5 \mathrm{~g}$ of acidity $/ \mathrm{m}^{2} / \mathrm{day}$. In the vicinity of oxygen, the bacterias (such as Desulfovibrio and Desulfotomaculum) in the compost can use other chemicals, such as ferric iron or sulfate as oxidants. Ferric iron turns to ferrous iron and sulfate becomes sulfide, producing bicarbonate in the process.

The sulphate is bacterially converted to hydrogen sulfide, bicarbonate alkalinity is produced as follows[7]-

$2 \mathrm{H}_{2} \mathrm{O}+\mathrm{SO}_{4}{ }^{2-}+\mathrm{C}$ (organic matter) $\Leftrightarrow \mathrm{H}_{2} \mathrm{~S}+2 \mathrm{HCO}_{3}^{-}$(bicarbonate alkalinity)

The mechanism and efficiency of AMD treatment vary with season and also with wetland age [25]. Anaerobic wetlands are most successful for treatment of small to moderate AMD water quality. A typical anaerobic/Compost wetland is shown in Figure 2.

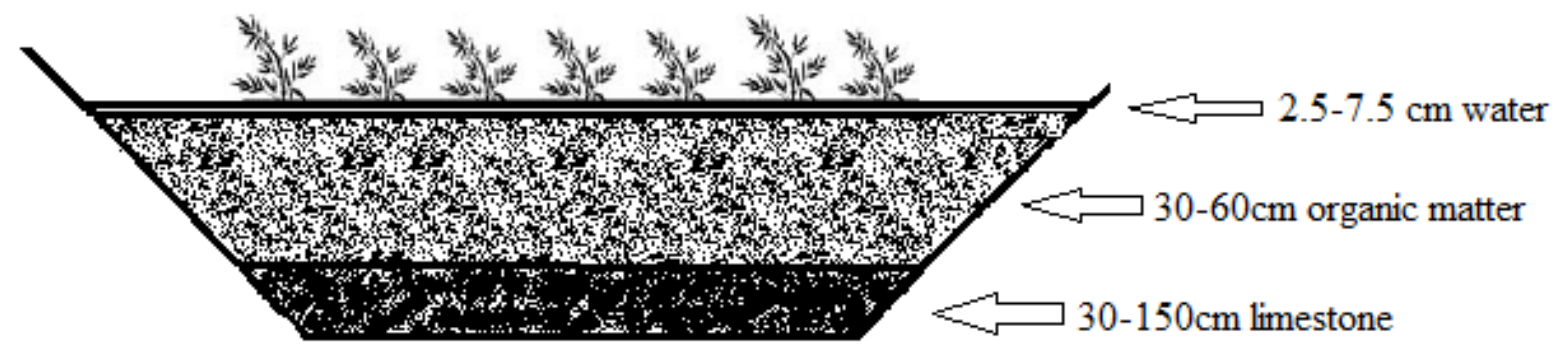

Fig.2.Typical anaerobic/Compost wetland

Open limestone channels (OLC):

OLCs may be the simplest version of passive treatment method. These are open channels that contain a coarse aggregate of limestone [26], and the water is diverted through. The typical OLC pond may have 0.3 meters to 1 meter of limestone at the bottom, and it should hold 1 meter to 3 meters of water to keep the seep and limestone under water [27].Various sized limestone are placed along bottom and sides of the channel, and the AMD flows through these limestone. OLC introduced alkalinity to acid mine water and supposed to raise the $\mathrm{pH}$ of the acid water to 6-8.

There are variable design factors like channel dimensions (specially length) and channel slope in the construction and use of this system for optimum performance. The drain length should is sufficiently long, so that mine drainage water gets enough contact time with limestone for proper neutralization. If the slope is more than 10 degrees, acid mine water will pass through the limestone aggregate too fast. Hence there will not be adequate neutralization. In too low slope drains heavy metal precipitates(armoring or the coating of the limestone ) will occur around limestone and within its void spaces and decreases the neutralizing capacity[7].

For efficient performance, channel gradient should be more than $20 \%$.OLC, when used with other passive treatment methods, can make the most of the treatment and remove the heavy and toxic metals[28].

Armoring of the limestone by $\mathrm{Fe}(\mathrm{CO})_{3}$ and $\mathrm{Fe}(\mathrm{OH})_{3}$ produced by neutralization decreases the generation of alkalinity, so huge amount of limestone are needed for the long success of the method. The high slope of OLD causes AMD water to flow fast along the ditch and hence turbulence is created. This high flow reduces armoring of the limestone and prevents precipitates to settle down. To prevent permeation of the AMD into the groundwater table, impermeable liners may be used under the limestone [29]. A typical cross section of an open limestone channel is shown in Figure 3.

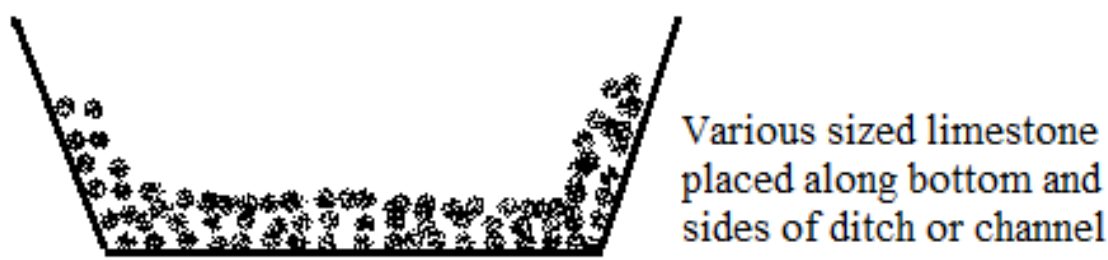

Fig.3.Cross section of an open limestone channel 


\section{Diversion Wells:}

Another simple method to add alkalinity to the AMD waters is diversion well. The diversion well is an easy mechanism at first designed for treatment of stream acidity created by acid rain in Norway and Sweden [30]. A schematic figure of diversion well is shown in figure 4.It has been adopted for AMD treatment in the eastern USA. A typical diversion well has an in-ground cylinder or vertical tank of metal or concrete, 1.5-1.8 $\mathrm{m}$ in diameter and 2-2.5 $\mathrm{m}$ in depth, filled with crushed limestone aggregate. A fraction of a fast flowing AMD watercourse is diverted and fed via a large pipe of diameter 20-30 cm that enters vertically down the axis of the well and ends shortly above the bottom[28].

Hydraulic force of the pipe flow agitates the bed of limestone particles. Thus these limestone particles are suspended (and) avoid armoring. The AMD flows up through the limestone, dissolves the limestone and thus alkalinity is generated, and metal flocs produced by hydrolysis and neutralization reactions are flushed through the system, and AMD water flows out the top of the well. This overflowed AMD water is diverted back into the main body of the stream.

For continues treatment of the diversion wells, they are regularly refilled with clean limestone and for maintenance leaves and other debris are frequently removed from the well to avoid blocking[29].

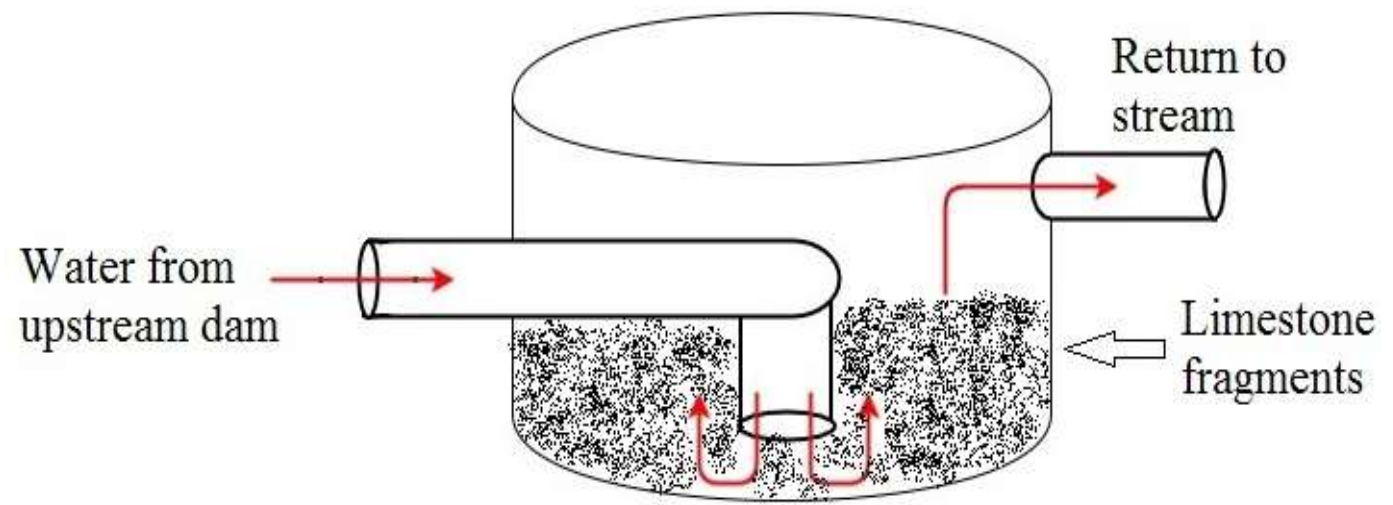

Fig.4. Schematic view of Diversion Well

\section{Anoxic Limestone Drains (ALD):}

An anoxic limestone drain (ALD) are below ground limestone aggregate beds (covered in plastic or impervious liner, and then capped with clay or compacted soil) along gently graded slopes [31], through which an unaerated effluent for eg., AMD, flows by gravity and limit the amount of atmospheric oxygen in the system.

With these capping of clay or organic matter, it is ensured that minimum or no air entrained into the drain[32].The exclusion of oxygen with AMD prevents oxidation of metals and clogging of the system.

The trenches have typical size $1.0 \mathrm{~m}$ thick, $1.0-7.0 \mathrm{~m}$ wide and 25-100 m long. The ALDS effluent $\mathrm{pH}$ typically ranges between 6.0 to 7.5.This system requires 14-15 hours retention time[3].

The prime function of an ALD is to provide bicarbonate alkalinity via limestone dissolution and to raise the pH of AMD to 6-8 hence converting net acid water into net alkaline water. The acidic water flowing through trench dissolves the limestone and releases bicarbonate alkalinity as shown by the equation below[13].

$\mathrm{CaCO}_{3}+\mathrm{H}^{+}=\mathrm{Ca}^{2+}+\mathrm{HCO}_{3}^{-}$

Prior to discharge to natural water bodies, the AMD effluent is held in a settling pond to raise its $\mathrm{pH}$ and metal precipitation. Anoxic Limestone Drains (ALD) is shown in Figure 5.

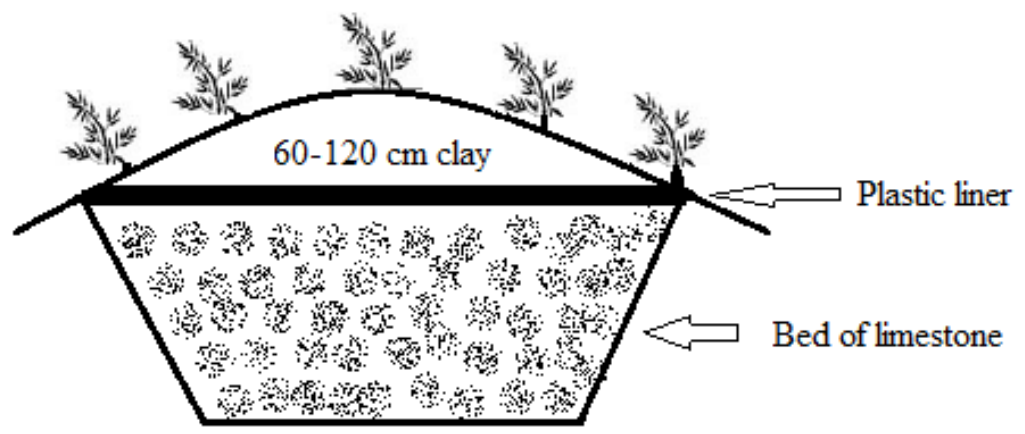

Fig.5.Anoxic Limestone Drains 


\section{IARJSET

\section{IV.CONCLUSION}

Open cast and underground mining are one such main industry that disburses various toxic metals and pollutants into the environment and considerably degrades the quality of environment and ecosystem. In coal mining, AMD is presently the major single reason for mine-related water pollution.

Mine influence water has many severe effects on nearby land and water resources. Little methodical research work has been carried out in India to study the pollution due to AMD. The paper summarizes the probable causes of pollution of AMD to the environment and enumerates the various techniques which could have been taken to minimize the pollution. With the aim of minimizing this pollution, care should be taken to make sure that rainwater does not get in touch with pyrite. The selection of a particular method depends on various economic and environmental factors.

Passive treatment techniques are mostly used for post-closure of mines and are best suited to AMD with low Acidity and low flow rates. Active treatment techniques usually require schedule addition of reagent and regular maintenance and can be designed to accommodate for any acidity, flow rate, and acidity load.

\section{ACKNOWLEDGMENT}

The authors are thankful to the department of mining engineering, Indian Institute of Technology, Banaras Hindu University, Varanasi for providing technical assistance and co-operation during the study.

\section{REFERENCES}

[1] European Commission. (2009). Reference Document on Best Available Techniques for Waste-Rock in Mining Activities Management of Tailings and, (January).

[2] Yadav, H.L. and Jamal, A. (2015). The Impact of Mining on Water Resources in India, International Journal of Advanced Research Volume 3, Issue 10, pp.1009-1015.

[3] Yadav, H. L., Jamal , A., 2016.Treatment of Acid Mine Drainage: A General Review.International Advanced Research Journal in Science, Engineering, and Technology,3(11),pp.116-122.

[4] Wang, L. P., Ponou, J., Matsuo, S., Okaya, K., Dodbiba, G., Nazuka, T., \& Fujita, T. (2013). Integrating sulfidization with neutralization treatment for selective recovery of copper and zinc over iron from acid mine drainage. Minerals Engineering, 45, $100-107$. https://doi.org/10.1016/j.mineng.2013.02.011

[5] Akcil, A., \& Koldas, S. (2006). Acid Mine Drainage (AMD): causes, treatment and case studies. Journal of Cleaner Production, 14(12-13 SPEC. ISS.), 1139-1145. https://doi.org/10.1016/j.jclepro.2004.09.006

[6] Skousen J., Politan, K., Hiltan, T. and Meek, A. (1990). Acid Mine Drainage Treatment Systems: Chemical and Costs, Green Lands.20 (4),pp.31-37.

[7] Taylor, J., Pape, S., \& Murphy, N. (2005). A Summary of Passive and Active Treatment Technologies for Acid and Metalliferous Drainage (AMD). Proceedings of the 5th Australian Workshop on Acid Drainage, (29), 1-49.

[8] Gaikwad, R. W., \& Gupta, D. V. (2007). Acid Mine Drainage ( AMD ) Management, 23(2).

[9] Cartwright, P. (1985). Membranes separations technology for industrial effluent treatment - a review. Desalination, 56, 17-35. https://doi.org/10.1016/0011-9164(85)85012-8

[10] Feng, D., Aldrich, C., \& Tan, H. (2000). Treatment of acid mine water by use of heavy metal precipitation and ion exchange. Minerals Engineering, 13(6), 623-642. https://doi.org/10.1016/S0892-6875(00)00045-5

[11] Dunbabin, J.S., Bowmer, K.H., (1992). The potential use of constructed wetlands for treatment of industrial waste waters containing metals. Science of the Total Environment 3, pp.151-168.

[12] Eger, P., Wagner, J., Kassa, Z., Melchert, G., (1994). Metal removal in wetland treatment systems. In: Proceedings of the International Land Reclamation and Mine Drainage Conference/Third International Conference on the Abatement of Acidic Drainage, Pittsburgh, PA, pp. $80-88$

[13] Corps, A., \& Concord, V. R. (2003). Passive and Semi-Active Treatment of Acid Rock Drainage From Metal Mines - State of the Practice, 113.

[14] Hyman, D.M., and G.R. Watzlaf. (1995). Mine drainage characterization for the successful design and evaluation of passive treatment systems. In: Proceedings, Seventeenth Annual Conference of the National Association of Abandoned Mine Lands, October 1995, French Lick, IN

[15] Skousen C., Zipper, J. Jage, C. (2016). Passive Treatment of Acid Mine Drainage. Reclamation Guidelines for Surface Mined Land Virginia Cooperative Extension, publication 460-133pp.1-15

[16] Canada, N. R., Ministry, O., Development, N., Centre, C., Technology, E., Ontario, N., \& Agreement, D. (1999). REVIEW OF PASSIVE SYSTEMS FOR TREATMENT OF ACID MINE DRAINAGE, (May 1996).

[17] Costello, Christine.2003. Acid Mine Drainage: Innovative Treatment Technologies.U.S. Environmental Protection Agency Office of Solid Waste and Emergency Response Technology Innovation Office Washington, DC www.clu-in.org.pp.1-47.

[18] Stankovi, M., \& Ana Luković. (n.d.). PASSIVE SYSTEMS FOR TREATING ACID MINE DRAINAGE: A GENERAL REVIEW DRAINAGE TO ACID, 227-232. https://doi.org/10.7562/SE2012.2.04.07.

[19] Skousen, J., and P.F. Ziemkiewicz (2005). "Performance of 116 passive treatment systems for acid mine drainage." Proceedings, American Society of Mining and Reclamation, Breckenridge, CO: 1100-1133.

[20] Christina Stuhlberger, Philip Peck, Gilles Tremblay, (2007).Innovative Techniques and Technologies for Contaminated Mine Waters Assessment, Management, and Remediation.Technical Workshop Report Brestovacka Spa, Bor, Serbia

[21] Zipper, C., Skousen, J. \&Jage, C., (2011). Passive treatment of acid mine drainage. Virginia Tech, Issue Reclamation guidelines for surface mined land.

[22] Skousen, J. G., A. Rose, et al. (1998). Handbook of Technologies for avoidance and remediation of acid mine drainage. Morgantown, The National Mine Land Reclamation

[23] Fennessy, S. and W.J. Mitsch. 1989. Design and use of wetlands for renovation of drainage from coal mines. IN Ecological Engineering: an Introduction to Ecotechnology. W.J. Mitsch and S.E.Jorgensen (Ed.), pp. 232-252. John Wiley \& Sons, New York, NY. 
[24] Hedin, R. S., Watzlaf, G. R., \& Nairn, R. W. (1994). Passive Treatment of Acid-Mine Drainage with Limestone. Journal of Environmental Quality, 23(6), 1338-1345. https://doi.org/10.2134/jeq1994.00472425002300060030x

[25] Wieder, R.K. 1988. Determining the capacity for metal retention in man-made wetlands constructed for treatment of coal mine drainage. p. 375381. In: Proceedings, Mine Drainage and Surface Mine Reclamation, Vol. 1, Info. Circular No. 9183.U.S. Bureau of Mines, April 19-21, 1988, Pittsburgh, PA.

[26] Ziemkiewicz, P. F., and Brant, D. L. (1996).The Casselman River Restoration Project. In: Proceedings Eighteenth West Virginia Surface Mine Drainage Task Force Symposium 1996, Morgantown, West Virginia.

[27] D. Johnson, K. Hallberg: "Pitfalls of passive mine water treatment," Re/Views Environ Sci Bio/Technol, Vol.1, 2002, pp. 335-43.

[28] Skousen, J. (1997). Overview of passive systems for treating acid mine drainage. Green Lands, 27(4), 34 43.Retrieved from http://anr.ext.wvu.edu/resources/295/1256049359.pdf\%5Cnhttp://www.wvu.edu/ agexten/landrec/passtrt/passtrt.htm

[29] DEP(2000).The science of acid mine drainage and passive treatment. Department of Environmental Protection, Bureau of Abandoned Mine Reclamation of Pennsylvania (Web site).K. 1992. The Kentucky wetlands project: A field study to evaluate manmade wetlands for acid coal mine drainage treatment. Final Report to the U.S. Office of Surface Mining, Villanova University, Villanova, PA

[30] Arnold, D.E. 1991. Diversion wells - A low-cost approach to treatment of acid mine drainage. In: Proceedings, Twelfth West Virginia Surface Mine Drainage Task Force Symposium, April 3-4, 1991, Morgantown, WV.

[31] Kilborn (1999). Review of Passive Systems for Treatment of Acid Mine Drainage. Mine Environment Neutral Drainage (MEND) Report 3.14.1.

[32] Hedin, R.S., R.W. Nairn, and R.L.P. Kleinmann. 1994. Passive treatment of coal mine drainage. U.S. Bureau of Mines Information Circular IC 9389. Pittsburgh, PA.

\section{BIOGRAPHY}

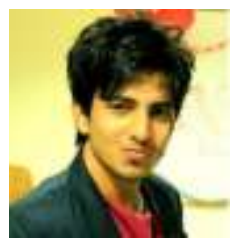

Vikram Seervi received his B.Tech degree in Mining Engineering from Visvesvaraya National Institute of Technology (VNIT), Nagpur in the year 2014. He is completing his M.Tech from Indian Institute of Technology, Banaras Hindu University (IIT BHU), Varanasi (U.P). His area of interest is mine planning and design and environmental management. 